\title{
Network-based analysis of calcium-binding protein genes identifies Grp94 as a target in human oral carcinogenesis
}

\author{
H Nomura', K Uzawa*, ,, , Y Yamano', K Fushimi', T Ishigami', Y Kato', K Saito', D Nakashima', M Higo', \\ Y Kouzu', K Ono' ${ }^{2}$ K Ogawara', M Shiiba', H Bukawa', H Yokoe ${ }^{2}$ and H Tanzawa' ${ }^{1,2,3}$ \\ 'Department of Clinical Molecular Biology, Graduate School of Medicine, Chiba University, I-8-I Inohana, Chuo-ku, Chiba 260-8670, Japan; ${ }^{2}$ Division of \\ Dentistry and Oral-Maxillofacial Surgery, Chiba University Hospital, I-8-I Inohana, Chuo-ku, Chiba 260-8670, Japan; ${ }^{3}$ Center of Excellence (COE) \\ Program in the 2Ist Century, Graduate School of Medicine, Chiba University, I-8-I Inohana, Chuo-ku, Chiba 260-8670, Japan
}

To characterise $\mathrm{Ca}^{2+}$-binding protein gene expression changes in oral squamous cell carcinomas (OSCCs), we compared the gene expression profiles in OSCC-derived cell lines with normal oral tissues. One hundred $\mathrm{Ca}^{2+}$-binding protein genes differentially expressed in OSCCs were identified, and genetic pathways associated with expression changes were generated. Among genes mapped to the network with the highest significance, glucose-regulated protein $94 \mathrm{kDa}$ (Grp94) was evaluated further for mRNA and protein expression in the OSCC cell lines, primary OSCCs, and oral premalignant lesions (OPLs). A significant ( $P<0.00 \mathrm{I}$ ) overexpression of Grp94 protein was observed in all cell lines compared to normal oral epithelium. Immunohistochemical analysis showed highly expressed Grp94 in primary OSCCs and OPLs, whereas most of the corresponding normal tissues had no protein immunoreaction. Real-time quantitative reverse transcriptase-PCR data agreed with the protein expression status. Moreover, overexpression of Grp94 in primary tumours was significantly $(P<0.00 \mathrm{I})$ correlated with poor disease-free survival. The results suggested that Grp94 may have potential clinical application as a novel diagnosis and prognostic biomarker for human OSCCs. British Journal of Cancer (2007) 97, 792-80I. doi: I0.1038/sj.bjc.6603948 www.bjcancer.com

Published online 28 August 2007

(c) 2007 Cancer Research UK

Keywords: oral squamous cell carcinoma; $\mathrm{Ca}^{2+}$-binding protein; pathway analysis; glucose-regulated protein $94 \mathrm{kDa}$; poor prognosis

Cytosolic $\mathrm{Ca}^{2+}$, a basic parameter of intracellular homeostasis, has a wide variety of important cellular functions, that is, cell growth and proliferation, processing and folding of endoplasmic reticulum (ER)-translated proteins, and $\mathrm{Ca}^{2+}$-mediated signalling in response to extracellular stimuli (Berridge et al, 2000; Kunzelmann, 2005). Under physiologic conditions, many aspects of these processes are mediated by members of the $\mathrm{Ca}^{2+}$-binding protein (Nelson and Chazin, 1998). Since considerable evidence shows that intracellular $\mathrm{Ca}^{2+}$ deregulation is crucial for tumour growth and development (Durham and Walton, 1982; Huang et al, 2005; Ding et al, 2006; Thebault et al, 2006), understanding the genetic mechanisms of the $\mathrm{Ca}^{2+}$-binding protein genes involved in carcinogenesis is imperative for the development of new therapeutic strategies.

$\mathrm{Ca}^{2+}$-binding protein is characterised by the presence of the putative $\mathrm{Ca}^{2+}$-binding domain; EF-hand structure is an essential mediator of intracellular $\mathrm{Ca}^{2+}$ control elements, such as the plasma membrane $\mathrm{Ca}^{2+}$ pumps or ER (Koch et al, 1986; Nelson and Chazin, 1998; Haeseleer et al, 2000). A number of $\mathrm{Ca}^{2+}$ binding proteins are thought to be implicated in establishing the malignant and metastatic phenotypes of various tumours (Chen et al, 1997; Takenaga et al, 1997; Van Ginkel et al, 1998), and recent studies have reported altered expression of several $\mathrm{Ca}^{2+}$ binding protein genes in a wide range of human malignancies (Bustin et al, 2001; Pietas et al, 2002; Lakshmikuttyamma et al,

*Correspondence: Dr K Uzawa; E-mail: uzawak@faculty.chiba-u.jp Revised 29 June 2007; accepted 31 July 2007; published online 28 August 2007
2004; Imazawa et al, 2005). Regarding oral squamous cell carcinomas (OSCCs), aberrant expression of S100 $\mathrm{Ca}^{2+}$-binding protein families seen in tumour sites has been correlated with cancer cell invasion or metastasis (Moriyama-Kita et al, 2004; Tsai et al, 2005). We recently identified certain $\mathrm{Ca}^{2+}$-binding protein genes differentially expressed in OSCCs compared with normal oral squamous epithelium, including PMCA1 (Saito et al, 2006), ITPKA (Kato et al, 2006), ATP2A2 (Endo et al, 2004), CALR (Shimada et al, 2005), and E-cadherin (Saito et al, 1998).

We recently developed the strategy of using a knowledge-based network approach to search for candidate genes relevant to the treatment of oral cancers (Kasamatsu et al, 2005; Higo et al, 2006; Ishigami et al, 2007). Thus, this study aimed to explore further the global changes in $\mathrm{Ca}^{2+}$-binding protein genes associated with OSCCs by applying network development tools to expand on microarray analysis methods. In addition, a candidate gene for therapeutic targeting and follow-up studies was evaluated further for the expression status of the mRNA and protein in a large series of OSCCs and oral premalignant lesions (OPLs).

\section{MATERIALS AND METHODS}

\section{Tissue specimens}

Eighty pairs of primary OSCC samples and corresponding normal oral epithelial tissues or 20 OPLs (diagnosed as oral leukoplakias) were obtained at the time of surgery performed at Chiba University Hospital between 1998 and 2005. All patients provided informed 
consent according to the protocol that was reviewed and approved by the Institutional Review Board of Chiba University before any procedures were performed. Postoperative follow-up data were collected until April 2006 or until the day of the patient's death, metastasis, or local recurrence. The median follow-up time was 2.1 years (range: 3 months to 8 years).

The resected tissues were divided into two parts: one was frozen immediately after removal of the surrounding normal tissue and stored at $-80^{\circ} \mathrm{C}$ until RNA extraction, and another was fixed in $10 \%$ buffered formaldehyde solution for pathologic diagnosis and immunohistochemical staining. Histopathologic diagnosis of each tumour specimen was performed according to the International Histological Classification of Tumours by the Department of Pathology, Chiba University Hospital. Clinicopathologic staging was determined by the TNM classification of the International Union against Cancer. All OSCC samples were histologically confirmed and checked to ensure the presence of tumour in greater than $80 \%$ of specimens.

Formalin-fixed, paraffin-embedded human breast cancer tissue (positive control for Grp94 expression) was purchased from Lab Vision Co., Fremont, CA, USA (GRP94, Ab-1, positive control for immunohistochemistry).

\section{Cell culture}

The OSCC-derived cell lines used in this study were HSC-2, HSC-3, Ca9-22 (Human Science Research Resources Bank, Osaka, Japan), H-1, Sa-3 (provided by Dr Fujita, Wakayama Medical University, Wakayama, Japan), and OK-92 (established from carcinoma of the tongue in our department) (Takahashi et al, 1989). All OSCCderived cell lines were cultured in Dulbecco's modified Eagle's medium F-12 HAM (Sigma-Aldrich Co., St Louis, MO, USA) supplied with $10 \%$ heat-inactivated fetal bovine serum (Sigma) and $50 \mathrm{U} \mathrm{ml}^{-1}$ penicillin and streptomycin (Sigma). The human normal oral keratinocytes (HNOKs) cell line was cultured and maintained in defined keratinocyte-SFM (Gibco BRL, Gaithusberg, Germany). All cell lines were incubated at $37^{\circ} \mathrm{C}$ in a humidified atmosphere with $5 \% \mathrm{CO}_{2}$.

\section{Protein and mRNA extraction}

Protein was extracted when the cells reached $80-90 \%$ confluence; they were washed two times with phosphate-buffered saline (PBS), scraped into a tube, and centrifuged briefly. The cell pellets were incubated for $30 \mathrm{~min}$ in a lysis buffer (LB) containing $7 \mathrm{M}$ urea, $2 \mathrm{M}$ thiourea, $4 \% \mathrm{wv}^{-1}$ CHAPS, and $10 \mathrm{~mm}$ Tris $\mathrm{pH} 8.0$, and lysed by sonication $(3 \times 10 \mathrm{~s}$ pulses on ice). The sample was centrifuged at 13000 r.p.m. for $20 \mathrm{~min}$. The supernatant containing the cell proteins then was recovered and the protein concentration was measured with a Protein Assay Kit (Bio-Rad Laboratories, Hercules, CA, USA) and adjusted to $1 \mathrm{mg} \mathrm{ml}^{-1}$ with LB. The $\mathrm{pH}$ of the protein sample was adjusted to 8.5 with $30 \mathrm{~mm}$ Tris- HCl. Total RNA was extracted using Trizol reagent (Invitrogen Life Technologies, Carlsbad, CA, USA) according to the manufacturer's instructions. Total protein extracted from a human breast cancer cell line, SKBR3 (positive control for Grp94 expression), was obtained from Lab Vision (GRP94, Ab-1, positive control for Western blotting). Each extracted RNA or protein was stored separately at $-80^{\circ} \mathrm{C}$ until use.

\section{Affymetrix GeneChip hybridisation}

Double-stranded cDNA was synthesised from $20 \mu \mathrm{g}$ of total RNA using the Superscript Choice system (Invitrogen). After phenol/ chloroform extraction and ethanol precipitation, a biotin-labelled in vitro transcription reaction was carried out using the cDNA template (Enzo Bioarray, Farmingdale, NY, USA). cRNA $(7 \mu \mathrm{g})$ was fragmented according to Affymetrix protocols and added to the recommended hybridisation mixture. Expression profiles were created using the Human Genome U 133 Plus 2.0 arrays containing 54675 probe sets (Affymetrix, Santa Clara, CA, USA). Arrays were stained with phycoerythrin-streptavidin, and the signal intensity was amplified by treatment with a biotin-conjugated antistreptavidin antibody followed by a second staining with phycoerythrin-streptavidin. Arrays stained a second time were scanned using the Affymetrix GeneChip Scanner 3000 (Affymetrix). Expression data were analysed using GeneChip Operating Software 1.1 (Affymetrix), and $\mathrm{Ca}^{2+}$-binding protein genes were then classified by GeneSpring 6.1 (Silicon Genetics, Redwood City, CA, USA).

\section{Network and gene ontology analysis}

A list of $\mathrm{Ca}^{2+}$-binding protein genes identified by microarray analysis was used for network and gene ontology analyses. Gene accession numbers were imported into the Ingenuity Pathway Analysis (IPA) Software (Ingenuity Systems, Mountain View, CA, USA). The IPA database consists of proprietary ontology representing 300000 biologic objects ranging from genes, proteins, and molecular and cellular processes. More than 11200 human genes are currently represented in the database. The genes were categorised based on location, cellular components, and reported or suggested biochemical, biologic, and molecular functions using the software. The identified genes also were mapped to genetic networks available in the Ingenuity database and then ranked by score. The score is the probability that a collection of genes equal to or greater than the number in a network could be achieved by chance alone. A score of 3 indicates a 1/1000 chance that the focus genes are in a network due to random chance. Therefore, a score of 3 or higher has a $99.9 \%$ confidence level of not being generated by random chance alone. This score was used as the cutoff for identifying gene networks.

\section{Western blot analysis}

Among genes identified, glucose-regulated protein $94 \mathrm{kDa}$ (Grp94) was selected for further analyses. We carried out Western blot analysis to investigate Grp94 protein expression in normal oral epithelium and OSCC-derived cell lines. Protein extracts were electrophoresed on $11 \%$ sodium dodecyl sulphate-polyacrylamide gel electrophoresis gels, transferred to polyvinylidene difluoride (PVDF) membranes (Bio-Rad Laboratories, Hercules, CA, USA), and blocked for $1 \mathrm{~h}$ at room temperature in 5\% skim milk. Immunoblot PVDF membranes were washed with $0.1 \%$ Tween-20 in TBS (TBS-T) five times, and $2 \mu \mathrm{g} \mathrm{ml}^{-1}$ affinity-purified rat antihuman Grp94 monoclonal antibody (Lab Vision) was added directly to the TBS-T solution for $2 \mathrm{~h}$ at room temperature. The PVDF membranes were washed again and incubated with $1: 10000$ ratio of horseradish peroxidase (HRP)-conjugated antirat IgG Ab (Santa Cruz Biotechnology, Santa Cruz, CA, USA) as a secondary antibody for $20 \mathrm{~min}$ at room temperature. The membranes were then incubated with enhanced chemiluminescence (ECL) + HRP substrate solution included in the ECL + kit (Amersham Biosciences, Buckinghamshire, UK), and immunoblotting was visualised by exposing the membrane to Hyperfilm (Amersham Biosciences). Triplicate examinations were performed to confirm the specificity of the antibody.

\section{Immunofluorescence}

The cells grown on glass coverslips were washed with PBS, fixed in $4 \%$ paraformaldehyde for $10 \mathrm{~min}$ at $37^{\circ} \mathrm{C}$ followed by absolute methanol for $10 \mathrm{~min}$ at $4{ }^{\circ} \mathrm{C}$, and blocked in PBS containing $1 \%$ skimmed milk for $10 \mathrm{~min}$. The samples then were incubated with anti-Grp94 antibody (Lab Vision) at a dilution of $1: 100$ for $2 \mathrm{~h}$, rinsed two times with PBS, and incubated with goat antirat 
secondary antibody labelled with Alexa Fluor 546 (Molecular Probes, Leiden, The Netherlands) for $1 \mathrm{~h}$. For counterstaining of the nucleus, the dishes were then incubated with $1 \mu \mathrm{g} \mathrm{ml}^{-1}$ Cellstain-DAPI (Dojindo Laboratories, Kumamoto, Japan) in PBS for $10 \mathrm{~min}$. The samples were observed under a Leica TCS2-MP confocal system (Leica Laserteknik, Mannheim, Germany) and Coherent Mira tunable pulsed titanium sapphire laser (Coherent Laser Group, Santa Clara, CA, USA).

\section{Immunohistochemistry}

To examine the cellular distribution of Grp94 protein in normal and OSCCs, we carried out immunohistochemical staining on $4-\mu \mathrm{m}$ sections of paraffin-embedded specimens. Briefly, after deparaffinisation and hydration, the slides were pretreated in $10 \mathrm{~mm}$ sodium citrate buffer $(\mathrm{pH} 6.0)$ in a microwave oven for $5 \mathrm{~min}$ at $95^{\circ} \mathrm{C}$. The endogenous peroxidase activity was quenched

Table I Genetic networks in the OSCC-derived cell lines

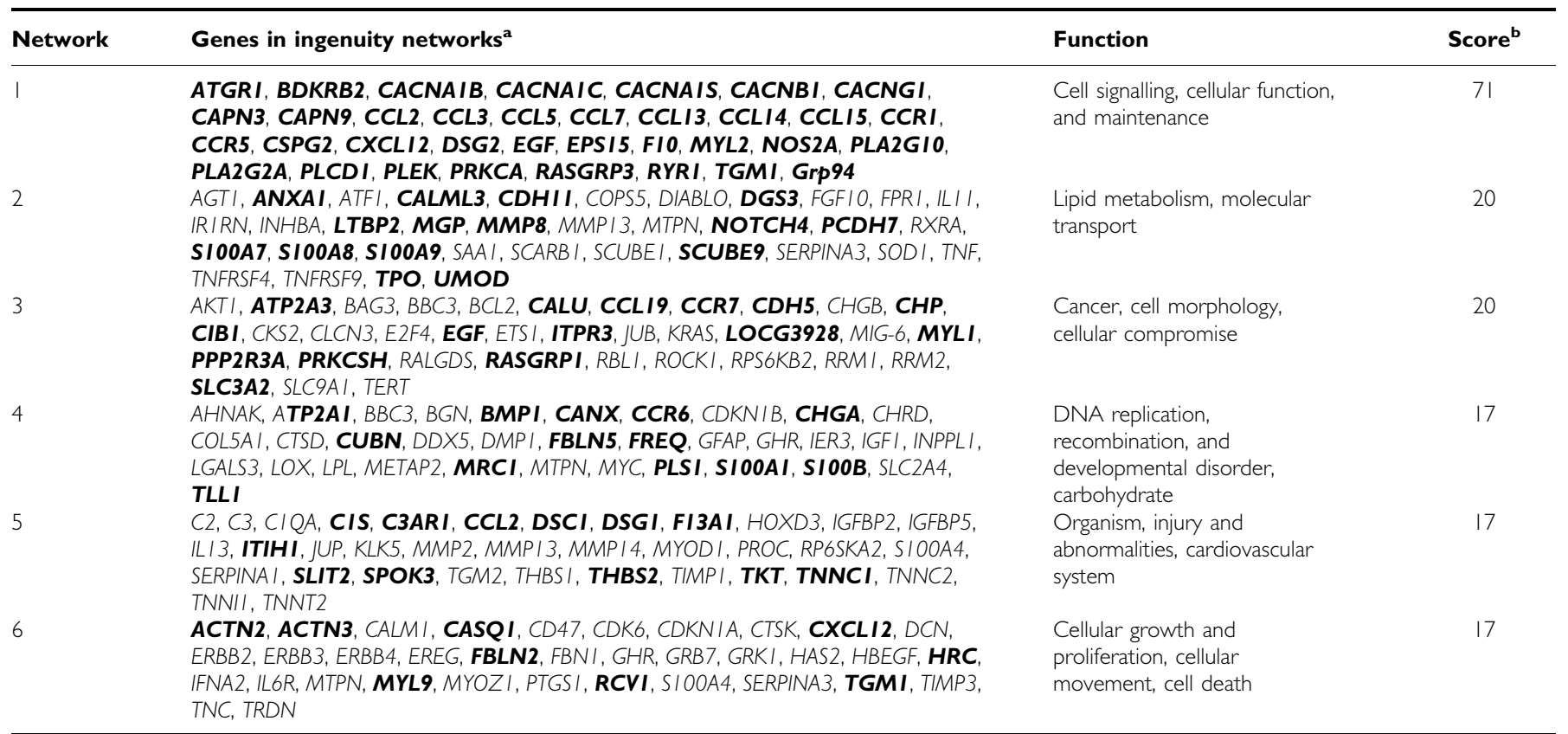

${ }^{a}$ Genes in boldface were identified by microarray analysis to be expressed differentially more than two-fold in OSCCs. Other genes were either not on the expression array or not significantly regulated. ${ }^{b} \mathrm{~A}$ score $>3$ was considered significant.

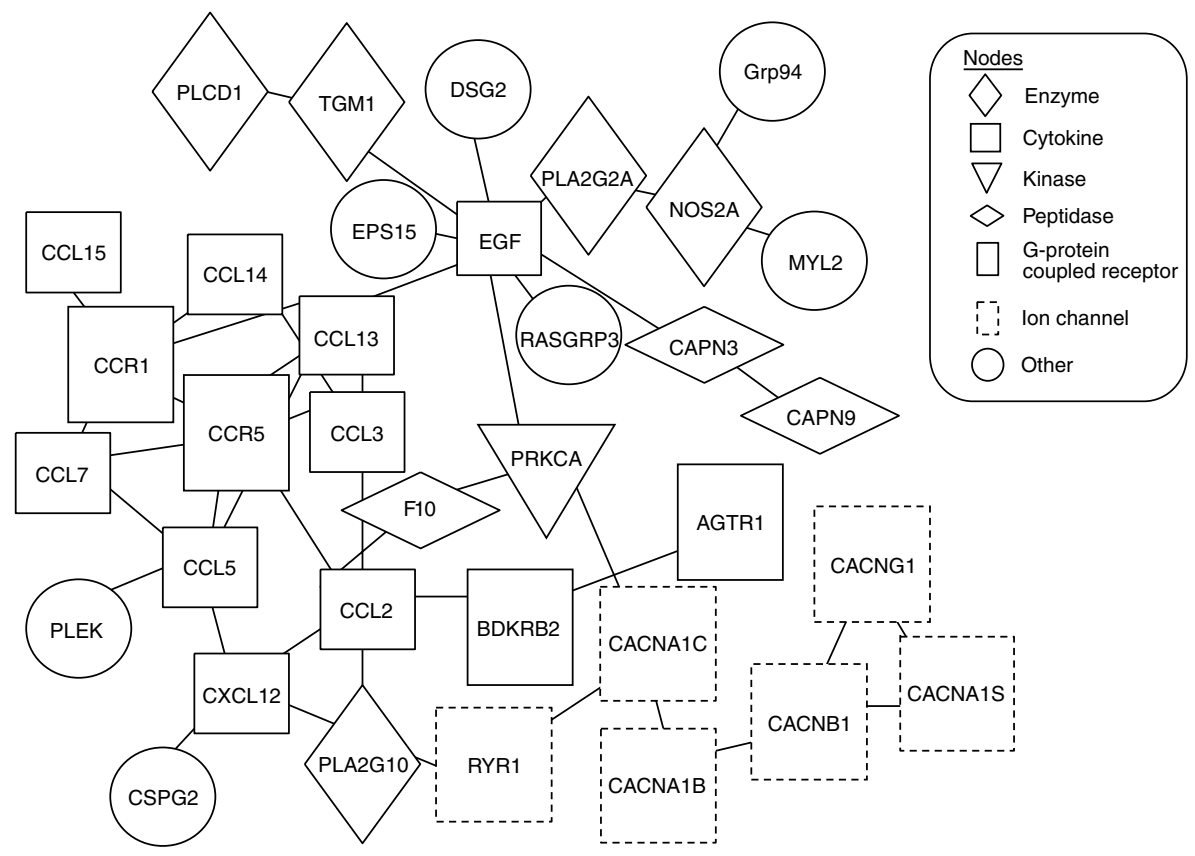

Figure I Network with the highest score (network I). Expression levels of all 35 genes (I00\%) are altered significantly in the oral squamous cell carcinomas (OSCCS). Functional relationships between gene products based on known interactions in ingenuity pathway analysis (IPA) knowledge are described. 
by 30 -min incubation in a mixture of $0.3 \%$ hydrogen peroxide solution in $100 \%$ methanol. After being washed with PBS buffer, sections then were incubated with primary antibody antiGrp94 antibody ( $1: 100$ dilution) at room temperature in a moist chamber for $2 \mathrm{~h}$. After being washed with PBS buffer, the slides were treated with biotinylated secondary antibody for $1 \mathrm{~h}$ followed by colour development in 3,3'-diaminobenzidine tetrahydrochloride (Dako Japan Inc., Kyoto, Japan). Finally, the slides were lightly counterstained with haematoxylin. A known positive breast cancer control section for Grp94 was clearly stained. While the breast cancer cells were immunohistochemically positive for Grp94, those of the negative control prepared by omitting the primary antibody were negative, thus confirming the staining specificity. To quantitate the state of the Grp94 protein expression, the mean percentage of positive tumour cells was determined in at least five random fields at $\times 400$ magnification in each section. The intensity of the Grp94 immunoreaction was scored as follows: $1+$, weak; $2+$, moderate; and $3+$, intense. The percentage of positive tumour cells and the staining intensity were then multiplied to produce a Grp94immunohistochemical staining score. Cases with a Grp94-immunohistochemical staining score exceeding 65.56 (maximum score of normal tissues) were considered positive. Two independent pathologists, neither of whom had knowledge of the patients' clinical status, made these judgments.

\section{mRNA expression analysis}

The expression levels of Grp94 mRNA were examined in 50 OSCC specimens from patients with primary tumours among the OSCC cases studied by immunohistochemical staining. Control reactions were prepared in parallel without reverse transcriptase (RT). Before cDNA synthesis, residual genomic DNA was removed from the total RNA using DNase I treatment (DNA-free; Ambion, Austin, TX, USA). The primer sequences used to analyse Grp94 mRNA expression were 5'-AGCAAGACGTGTTCGATTC-3' (nucleotides $1392-1410)$ and $5^{\prime}$-CCTCAATTTTGTCAAGGGTG-3' (nucleotides 1607-1626). The sequences of specific primers were checked before use to avoid amplification of genomic DNA or pseudogenes by the Primer3 program (available at http:wwwgenome.wi.mit.edu/cgi-bin/primer/primer3_www.cgi). Amplified products were analysed by $3 \%$ agarose gel electrophoresis to ascertain size and purity. Real-time quantitative RT (qRT)-PCR

Table 2 Thirty-five focus genes in network ।

\begin{tabular}{|c|c|c|c|c|}
\hline Affymetrix no. & Gene & Molecular function & Location & Fold change $^{a}$ \\
\hline 217901_at & DSG2 & Cell adhesion & Plasma membrane & 85.187 \\
\hline 200599_s_at & Grp94 & Protein folding and sorting, antigen presentation & Plasma membrane & 5.479 \\
\hline 210037_s_at & NOS2A & Nitric oxide synthase activity & Cytoplasm & 5.072 \\
\hline 1560074_at & PRKCA & Protein kinase $C$ activity & Cytoplasm & 3.781 \\
\hline 210641_at & CAPN9 & Calpain activity & Unknown & 3.003 \\
\hline 207|62_s_at & CACNAIB & Voltage-gated calcium channel activity & Plasma membrane & 2.894 \\
\hline 207222_at & PLA2GIO & Unknown & Extracellular space & 2.749 \\
\hline 207225_at & EPSI 5 & Protein binding & Plasma membrane & 0.4539 \\
\hline 20151I_at & BDKRB2 & Receptor activity & Plasma membrane & 0.4464 \\
\hline 205434_s_at & CACNAIC & Voltage-gated calcium channel activity & Plasma membrane & 0.4288 \\
\hline 218075_at & AGTRI & Receptor activity & Plasma membrane & 0.3305 \\
\hline 1558450_at & CCRI & Chemokine receptor activity & Plasma membrane & 0.2580 \\
\hline 207798_s_at & CACNBI & Voltage-gated calcium channel activity & Plasma membrane & 0.2346 \\
\hline 228767_at & CCLI3 & Chemokine receptor activity & Extracellular space & 0.2200 \\
\hline 235070_at & PLEK & Reorganisation & Cytoplasm & 0.1697 \\
\hline 229819_at & CCR5 & Chemokine receptor activity & Plasma membrane & 0.1640 \\
\hline 228376_at & CCL7 & Chemokine receptor activity & Extracellular space & 0.1611 \\
\hline 218529_at & $\mathrm{FIO}$ & Peptidase activity & Extracellular space & 0.1583 \\
\hline 224938_at & PLA2G2A & Protein binding & Extracellular space & 0.1339 \\
\hline 224939_at & CACNAIS & Voltage-gated calcium channel activity & Plasma membrane & 0.1256 \\
\hline 214711_at & CCL5 & Chemokine receptor activity & Extracellular space & 0.1172 \\
\hline 214319_at & $\mathrm{CCL} 3$ & Chemokine receptor activity & Extracellular space & 0.1071 \\
\hline | 555904_at & CCLI5 & Chemokine receptor activity & Extracellular space & 0.0868 \\
\hline 209665_at & RASGRP3 & Protein binding & Cytoplasm & 0.0810 \\
\hline 22078I_at & CACNGI & Voltage-gated calcium channel activity & Plasma membrane & 0.0744 \\
\hline 1553086_at & CSPG2 & Unknown & Extracellular space & 0.0736 \\
\hline 212698_s_at & EGF & Protein binding & Extracellular space & 0.0611 \\
\hline 226627_at & PLCDI & Unknown & Cytoplasm & 0.0381 \\
\hline 213666_at & CXCLI2 & Chemokine receptor activity & Extracellular space & 0.0350 \\
\hline 211890_x_at & CAPN3 & Calpain activity & Cytoplasm & 0.0227 \\
\hline 216598_s_at & CCL2 & Chemokine receptor activity & Extracellular space & 0.0198 \\
\hline 235340_at & CCLI4 & Chemokine receptor activity & Extracellular space & 0.0165 \\
\hline 205485_at & RYRI & Voltage-gated calcium channel activity & Plasma membrane & 0.0126 \\
\hline 206008_at & TGMI & Cell formation & Plasma membrane & 0.0109 \\
\hline 209742_s_at & MYL2 & Motor activity & Cytoplasm & 0.0100 \\
\hline
\end{tabular}

AGTRI = angiotensin II receptor, type I; BDKRB2 = bradykinin receptor B2; CACNAIB = calcium channel, voltage-dependent, $L$ type, $\alpha$ IB- subunit; CACNAIC = calcium channel, voltage-dependent, $\mathrm{L}$ type, $\alpha$ IC subunit; CACNAIS = calcium channel, voltage-dependent, $\mathrm{L}$ type, $\alpha$ IS subunit; CACNBI = calcium channel, voltage-dependent, $\beta$ I subunit; CACNGI = calcium channel, voltage-dependent, $\gamma$ subunit I; CAPN3=calpain 3, (p94); CAPN9=calpain 9; CCL2= chemokine (C-C motif) ligand 2; $\mathrm{CCL} 3=$ chemokine (C-C motif) ligand 3; CCL5= chemokine (C-C motif) ligand 5; CCL7= chemokine (C-C motif) ligand 7; CCLI3= chemokine (C-C motif) ligand I3; CCLI4 = chemokine (C-C motif) ligand 14; CCLI5= chemokine (C-C motif) ligand I5; CCRIchemokine (C-C motif); CCR5=chemokine (C-C motif) receptor 5; CSPG2 = chondroitin sulfate proteoglycan 2; CXCLI2 = chemokine (C-X-C motif) ligand I2; DSG2= desmoglein 2; EGF = epidermal growth factor; EPS I $5=$ epidermal growth factor receptor pathway substrate 15; FIO= coagulation factor X; Grp94= glucose regulated protein, $94 \mathrm{kDa}$; MYL2 = myosin, light polypeptide 2, regulatory, cardiac, slow; NOS2A = nitric oxide synthase 2A; PLA2G2A = phospholipase A2, group IIA; PLA2G I0 = phospholipase A2, group X; PLCDI = phospholipase C, delta I; PLEK= pleckstrin; PRKCA $=$ protein kinase $C, \alpha$; RASGRP3 = RAS guanyl releasing protein 3; RYRI = ryanodine receptor I; TGMI = transglutaminase I. ${ }^{\text {a } F o l d ~ o v e r e x p r e s s i o n ~ f o r ~ m i c r o a r r a y ~ d a t a ~}$ of OSCC-derived cell lines compared to normal control. 
was performed with a single method using the LightCycler FastStart DNA Master SYBR Green I kit (Roche, Mannheim, Germany). To prepare the standard curve, $3 \mu \mathrm{g}$ of total RNA from normal oral tissue was reverse-transcribed with Superscript RT (Life Technologies, Grand Island, NY, USA) and oligo-d(T)12-18 primer, after which serial dilutions were made corresponding to cDNA transcribed from 300, 30, 3.0, and 0.3 ng of total RNA. PCRs using LightCycler apparatus were carried out in a final volume of $20 \mu \mathrm{l}$ of reaction mixture consisting of $2 \mu \mathrm{l}$ of FirstStart DNA Master SYBR Green I mix, $3 \mathrm{~mm} \mathrm{MgCl}_{2}$, and $0.2 \mu \mathrm{l}$ of primers, according to the manufacturer's instructions. The reaction mixture then was loaded into glass capillary tubes and submitted to an initial denaturation at $95^{\circ} \mathrm{C}$ for $10 \mathrm{~min}$, followed by 45 rounds of amplification at $\left.95^{\circ} \mathrm{C} 10 \mathrm{~s}\right)$ for denaturation, $58^{\circ} \mathrm{C}(10 \mathrm{~s})$ for annealing and $72^{\circ} \mathrm{C}$ for extension, with a temperature slope of $20^{\circ} \mathrm{C} \mathrm{s}^{-1}$, performed in the LightCycler. The transcript amount for Grp94 was estimated from the respective standard curves and normalised to the GAPDH transcript amount determined in corresponding samples.

\section{Statistical analysis}

Differences in gene expression levels between Grp94-positive and Grp94-negative cases were calculated with the Mann-Whitney's $U$-test. Correlations between Grp94-immunohistochemical staining scores and clinicopathologic features were evaluated by Fisher's exact test. Overall survival time was defined as the interval between the date of treatment and the date of death or until the last objective follow-up information was obtained. Disease-free survival time was regarded as the time interval between tumour treatment and detection of the first locoregional recurrence, distant metastasis, or both or the date of the last follow-up, whichever occurred first. Patients without evidence of disease (local recurrence or metastasis) during follow-up were considered to have a good prognosis; patients with local recurrence, distant metastasis during follow-up were regarded as having a poor prognosis. Survival curves were obtained by the Kaplan-Meier method and differences in survival rates between Grp94-positive and Grp94-negative cases were compared by log-rank tests with $95 \%$ significance. The criterion for statistical significance was $P<0.05$. The data are expressed as the mean values \pm s.e.

\section{RESULTS}

\section{Altered $\mathrm{Ca}^{2+-}$ binding protein genes expression in OSCC-derived cell lines}

To investigate the expression profile changes of $\mathrm{Ca}^{2+}$-binding protein genes in OSCC, we initially performed oligonucleotide microarray analyses using the Affymetrix U133A chips, which contained 54675 probe sets with RNAs isolated from four OSCCderived cell lines (HSC-2, HSC-3, H-1, and Sa-3). Control RNAs consisted of a pool made of normal tongue tissue RNAs extracted from three patients. Expression data were analysed using the GeneChip Operating Software 1.1 (Affymetrix) and GeneSpring 6.1 (Silicon Genetics). Of the $2241 \mathrm{Ca}^{2+}$-binding protein gene transcripts analysed, $100(4.4 \%)$ were identified as genes that were differentially expressed at least two-fold in all OSCC-derived cell lines examined compared with controls. Of these, 24 genes were found to be upregulated and 76 genes were downregulated in OSCC (data not shown).

\section{Network and gene ontology analysis}

On the basis of all genes identified as described previously (referred to as focus genes), new and expanded pathway maps and connections and specific gene-gene interactions were inferred, functionally analysed, and used to build on the existing pathway using the IPA knowledge base. To generate networks, the knowledge base was queried for interactions between focus genes and all other gene objects stored in the database. Six networks were found to be significant in OSCC in that they had more of the identified genes present than would be expected by chance (Table 1). Of them, the network with the highest score (network 1 , score $=71$ ) was generated with all focus genes (Figure 1; Table 2). We also performed gene ontology analyses of 100 focus genes using the IPA tool. Seventy-six upregulated genes were associated with cancer-related functions, cell death, and the cell cycle; 24 downregulated genes were associated with cellular movement, signalling, and function and maintenance (Table 3 ). In particular, we found that the cellular signalling was contained in both the upregulated and downregulated groups. Six upregulated genes were associated with a variety of cellular signalling functions, including induction/production of nitric oxide, inhibition of cyclic adenosine monophosphate, and inactivation of mitogen-activated protein kinase. In contrast, 31 downregulated groups played a critical role in cellular signalling, which is related

Table 3 Functional characterisation of $\mathrm{Ca}^{2+}$-binding protein genes altered expressed in OSCC-derived cell lines

\begin{tabular}{|c|c|c|}
\hline Relevant function and disease & $P$-value & $\begin{array}{c}\text { Gene, } \\
\text { no }^{\mathbf{a}}\end{array}$ \\
\hline \multicolumn{3}{|c|}{ Top-10 functions associated with upregulated genes in OSCC-derived cell lines } \\
\hline Cancer ${ }^{\mathrm{b}}$ & $\begin{array}{l}\text { I.15E-3 to } \\
4.27 \mathrm{E}-2\end{array}$ & 7 \\
\hline Cell death & $\begin{array}{l}1.15 \mathrm{E}-3 \text { to } \\
6.42 \mathrm{E}-2\end{array}$ & 4 \\
\hline Cell cycle & $\begin{array}{l}1.86 \mathrm{E}-3 \text { to } \\
6.95 \mathrm{E}-2\end{array}$ & 6 \\
\hline Cell-to-cell signalling and interaction & $\begin{array}{l}3.94 \mathrm{E}-3 \text { to } \\
6.16 \mathrm{E}-2\end{array}$ & 7 \\
\hline Cell signalling & $\begin{array}{l}3.29 \mathrm{E}-3 \text { to } \\
6.42 \mathrm{E}-2\end{array}$ & 6 \\
\hline Molecular transport & $\begin{array}{l}4.29 \mathrm{E}-3 \text { to } \\
7.47 \mathrm{E}-2\end{array}$ & 5 \\
\hline Small molecule biochemistry & $\begin{array}{l}4.29 \mathrm{E}-3 \text { to } \\
7.47 \mathrm{E}-2\end{array}$ & 9 \\
\hline Nucleic acid metabolism & $\begin{array}{l}5.07 \mathrm{E}-3 \text { to } \\
2.89 \mathrm{E}-2\end{array}$ & 4 \\
\hline Cellular growth and proliferation & $\begin{array}{l}5.07 \mathrm{E}-3 \text { to } \\
6.95 \mathrm{E}-2\end{array}$ & 3 \\
\hline Cell morphology & $\begin{array}{l}8.24 \mathrm{E}-3 \text { to } \\
6.95 \mathrm{E}-2\end{array}$ & । \\
\hline \multicolumn{3}{|c|}{ Top-10 functions associated with downregulated genes in OSCC-derived cell lines } \\
\hline Cellular movement ${ }^{\mathrm{c}}$ & $\begin{array}{l}1.60 \mathrm{E}-13 \text { to } \\
8.53 \mathrm{E}-3\end{array}$ & 33 \\
\hline Cellular signalling & $\begin{array}{l}1.52 \mathrm{E}-11 \text { to } \\
8.53 \mathrm{E}-3\end{array}$ & 31 \\
\hline Cellular function and maintenance & $\begin{array}{l}1.52 \mathrm{E}-11 \text { to } \\
8.53 \mathrm{E}-3\end{array}$ & 16 \\
\hline Small molecule biochemistry & $\begin{array}{l}1.52 \mathrm{E}-11 \text { to } \\
8.53 \mathrm{E}-3\end{array}$ & 20 \\
\hline Vitamin and mineral metabolism & $\begin{array}{l}1.52 \mathrm{E}-11 \text { to } \\
7.02 \mathrm{E}-3\end{array}$ & 32 \\
\hline Tissue morphology & $\begin{array}{l}2.10 \mathrm{E}-11 \text { to } \\
8.53 \mathrm{E}-3\end{array}$ & 33 \\
\hline Molecular transport & $\begin{array}{l}2.69 \mathrm{E}-11 \text { to } \\
8.53 \mathrm{E}-3\end{array}$ & 18 \\
\hline $\begin{array}{l}\text { Skeletal and vascular system development and } \\
\text { function }\end{array}$ & $\begin{array}{l}2.08 \mathrm{E}-10 \text { to } \\
8.53 \mathrm{E}-3\end{array}$ & 21 \\
\hline Cancer & $\begin{array}{l}5.13 \mathrm{E}-9 \text { to } \\
8.53 \mathrm{E}-3\end{array}$ & 27 \\
\hline Cell-to-cell signalling and interaction & $\begin{array}{l}1.01 \mathrm{E}-8 \text { to } \\
8.53 \mathrm{E}-3\end{array}$ & 26 \\
\hline
\end{tabular}

aNumber of associated genes. ${ }^{b}$ Apoptosis, cell movement, proliferation, cell cycle progression, migration, binding quantity of cancer cell line. 'Chemotaxis, migration, cell movement, mobilisation of haematologic cyte. 
to intracellular $\mathrm{Ca}^{2+}$ homeostasis, suggesting that genes associated with cell signalling may act in a different manner during development of OSCC.

Among genes mapped to the network with the highest significance, Grp94 was analysed further.

\section{GRP94 expression in OSCCs}

The state of Grp94 protein expression in six OSCC-derived cell lines (HSC-2, HSC-3, H-1, Sa-3, Ca9-22, and OK-92) $(n=6)$ was evaluated by Western blot analysis. Figure $2 \mathrm{~A}$ shows representative results. The band size was found to be $94 \mathrm{kDa}$ as a single band, as reported by Little et al (1994). A significant $(P<0.001)$ overexpression of Grp94 protein was observed in all OSCC-derived cell lines compared with normal oral epithelium. We also assessed the level of Grp94 protein expression in an OSCC-derived cell line (HSC-3) and HNOKs by immunofluorescence analysis. Represen- tative cases of immunofluorescence are shown in Figure 2B. Strong immunoreactivity of Grp94 protein was detected in the cytoplasm of the OSCC-derived cell line HSC-3 compared with the HNOKs.

Immunohistochemical staining was performed using a series of surgical OSCC specimens, including 80 OSCCs with corresponding normal tissues and 20 OPLs. Grp94 overexpression was found not only in OSCCs $(P<0.001)$ but also in OPLs $(P<0.001)$. Among the OSCCs, 46 had significantly increased expression of Grp94 (immunohistochemical staining score, $>65.56$ ). In contrast, the normal tissues had no or significant downregulation of Grp94 expression and were considered Grp94 negative (Fisher's exact test). There was no significant difference between the frequency of Grp94-positive cases and clinicopathologic features (Table 4).

Thirteen of 20 (65\%) OPLs were defined as Grp94 positive. The Grp94-immunohistochemical staining scores for normal tissues, OPLs, and OSCCs, respectively, ranged from 0 to 65 (mean, 12.173), 12 to 191 (mean, 85.27), and 0 to 262 (mean, 106.511)

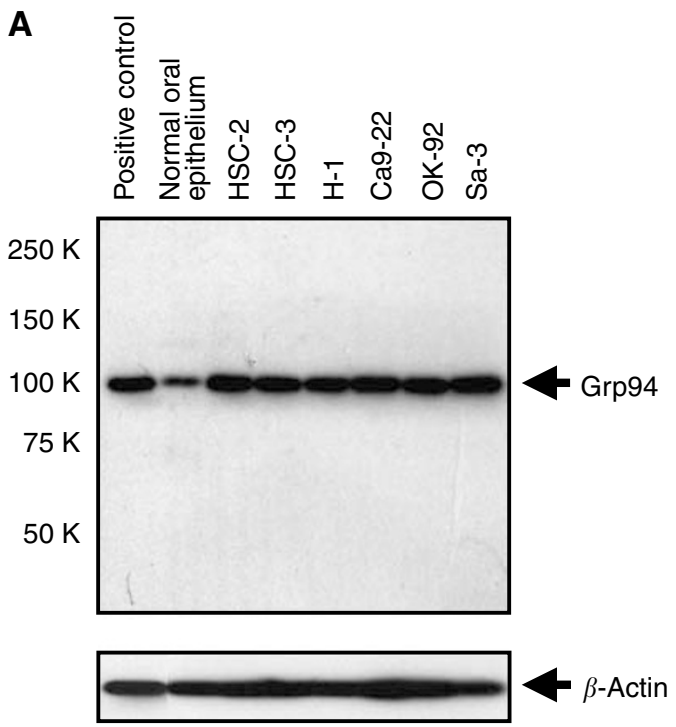

B
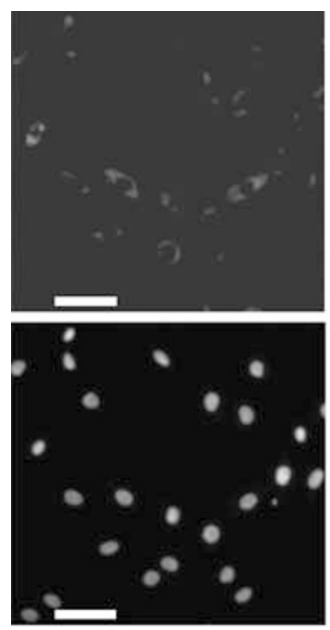

HSC-3
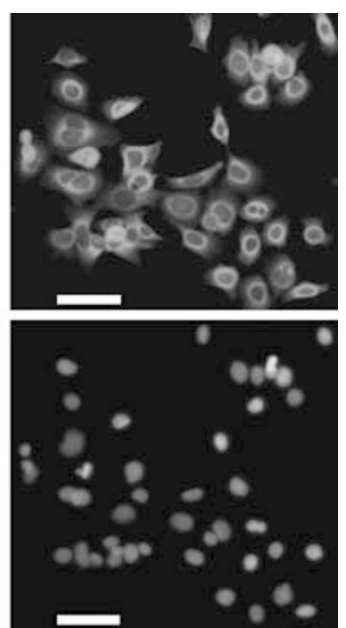

C

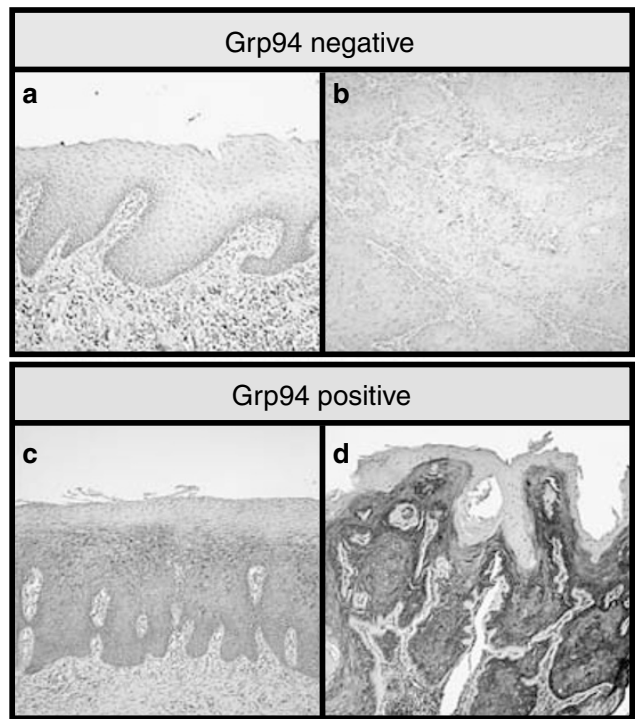

Figure 2 Representative results of expression of Grp94 protein in oral squamous cell carcinomas (OSCC)-derived cell lines. (A) Western blot analysis of Grp94 protein in OSCC-derived cell lines and normal oral epithelium. All OSCC-derived cell line extracts exhibit a single band for Grp94 protein expression at high levels. In contrast, normal oral epithelium shows a low level of Grp94 protein expression. (B) Immunocytochemical analysis shows strong immunoreactivity of Grp94 in an OSCC-derived cell line (HSC-3) compared with human normal oral keratinocytes (HNOKs). DAPI staining was used to stain DNA. Bar, $100 \mu \mathrm{m}$. (C) Immunohistochemical staining of Grp94 in normal tissue, oral premalignant lesion (OPL), and primary OSCC. (a) Normal oral tissue exhibits negative Grp94 protein expression. (b) Grp94-negative case of OSCC. (c) Grp94-positive case of OPL. The immunoreaction is enhanced in the spinous layer. (d) Grp94-positive case of OSCC. Strong positive immunoreactivity for Grp94 is detected in the cytoplasm. 
Table 4 Correlation between Grp94 expression and clinical classification in OSCCs

\begin{tabular}{|c|c|c|c|c|}
\hline \multirow[b]{2}{*}{ Clinical classification } & \multirow[b]{2}{*}{ Total } & \multicolumn{2}{|c|}{$\begin{array}{l}\text { Result of immunostaining: } \\
\text { number of patients(\%) }\end{array}$} & \multirow[b]{2}{*}{$P$-value ${ }^{a}$} \\
\hline & & Grp94 (-) & Grp94 (+) & \\
\hline \multicolumn{5}{|l|}{ Age at surgery (years) } \\
\hline$<60$ & 23 & $8(30)$ & $15(70)$ & \\
\hline $60 \leqslant,<70$ & 26 & II (42) & $15(58)$ & 0.431974 \\
\hline $70 \leqslant$ & 31 & $15(48)$ & $16(52)$ & \\
\hline \multicolumn{5}{|l|}{ Gender } \\
\hline Male & 33 & $13(39)$ & $20(61)$ & 0.654387 \\
\hline Female & 47 & $21(45)$ & $26(55)$ & \\
\hline \multicolumn{5}{|l|}{ T-primary tumour } \\
\hline $\mathrm{TI}$ & 5 & $2(40)$ & $3(60)$ & \\
\hline $\mathrm{T} 2$ & 35 & $15(43)$ & $20(57)$ & 0.55542 \\
\hline T3 & 17 & $5(29)$ & $12(7 \mid)$ & \\
\hline $\mathrm{T} 4$ & 23 & $12(52)$ & II (48) & \\
\hline \multicolumn{5}{|l|}{ N-regional lymph node } \\
\hline$N(-)$ & 52 & $23(44)$ & $29(56)$ & 0.813185 \\
\hline$N(+)$ & 28 & II (39) & $17(6 \mid)$ & \\
\hline \multicolumn{5}{|l|}{ Stage } \\
\hline I & 5 & $2(40)$ & $3(60)$ & \\
\hline$\|$ & 16 & $7(44)$ & $9(56)$ & 0.756529 \\
\hline III & 17 & $7(41)$ & $10(59)$ & \\
\hline IV & 52 & $28(54)$ & $24(46)$ & \\
\hline \multicolumn{5}{|l|}{ Histopathologic type } \\
\hline Well differentiated & 51 & $24(47)$ & $27(53)$ & \\
\hline Moderately differentiated & 22 & $9(41)$ & $13(59)$ & 0.300615 \\
\hline Poorly differentiated & 7 & I (14) & $6(86)$ & \\
\hline \multicolumn{5}{|l|}{ Tumour site } \\
\hline Tongue & 34 & $12(35)$ & $22(65)$ & \\
\hline Gingiva & 29 & $13(45)$ & $16(55)$ & 0.90283 \\
\hline Oral floor & 7 & $3(43)$ & 4 (57) & \\
\hline Buccal mucosa & 6 & $3(50)$ & $3(50)$ & \\
\hline Oropharynx & 3 & $2(67)$ & I (33) & \\
\hline Lip & 1 & $0(0)$ & I (100) & \\
\hline Leukoplakia & 20 & 7 (35) & $13(65)$ & - \\
\hline
\end{tabular}

${ }^{a} P<0.05$ was considered significant.

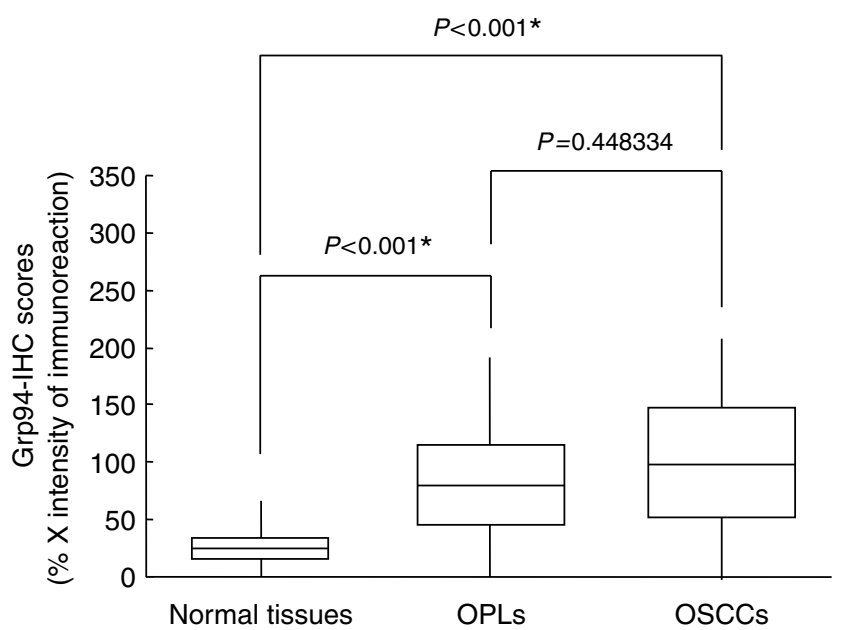

Figure 3 State of Grp94 protein expression in normal tissues $(n=80)$ oral premalignant lesions (OPLs) $(n=20)$ and primary oral squamous cell carcinomas (OSCCs) $(n=80)$. Grp94 protein expression in OPLs and OSCCs is significantly higher than in normal oral tissues $(P<0.00$ I, MannWhitney's $U$-test). The results are expressed as the mean \pm s.d.
A $\left(\times 10^{2}\right)$

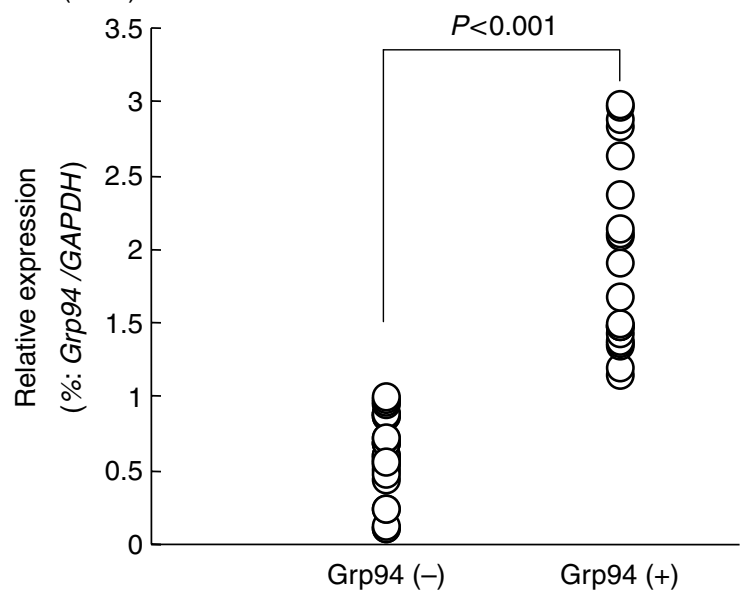

B $\left(\times 10^{2}\right)$

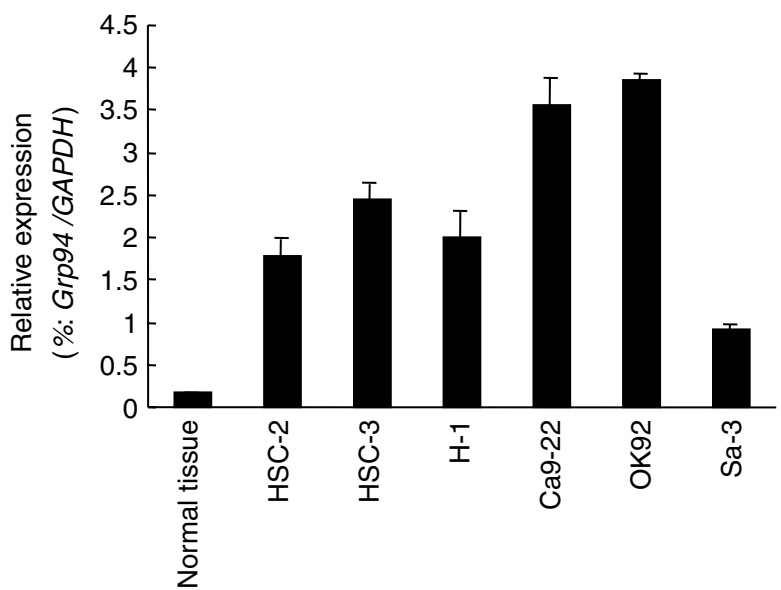

Figure 4 Grp94 mRNA expression status in primary oral squamous cell carcinomas (OSCCs) and OSCC-derived cell lines. (A) Comparison of Grp94 mRNA expression levels between Grp94-positive and Grp94negative cases classified by immunohistochemical analysis. There is a significant difference in the Grp94 mRNA expression levels between the negative and positive cases $(P<0.00 \mathrm{I}$, Mann-Whitney's U-test). (B) Quantification of mRNA levels in OSCC-derived cell lines by qRT-PCR analysis. Significant upregulation of Grp94 mRNA expression is seen in all OSCC-derived cell lines examined compared to normal oral epithelium. Data are expressed as the means \pm s.d.

(Figure 2C). Grp94 expression levels in primary OSCCs and OPLs were significantly $(P<0.001)$ higher than those in normal oral tissues (Figure 3 ). In contrast, we found no significant $(P=0.448334)$ difference in Grp94-immunohistochemical staining scores between OSCCs and OPLs.

Grp94 mRNA expression levels were significantly upregulated in primary tumours of randomly selected Grp94-positive cases $(n=29)$ compared to selected Grp94-negative cases $(n=21$, Mann-Whitney $U$-test, $P<0.001$; Figure $4 \mathrm{~A})$. mRNA expression levels were normalised to GAPDH. The relative mRNA expression levels in positive and negative cases ranged from 113 to 297 (mean, 191.3) and 9 to 88 (mean, 56.6), respectively. Grp94 expression was upregulated significantly in all OSCC cell lines examined compared to normal oral epithelium used as a control (Figure 4B).

\section{Prognostic significance of GRP94 expression in OSCCs}

To assess whether Grp94 expression also had a prognostic impact on patients with OSCC, clinical postoperative data from patients 

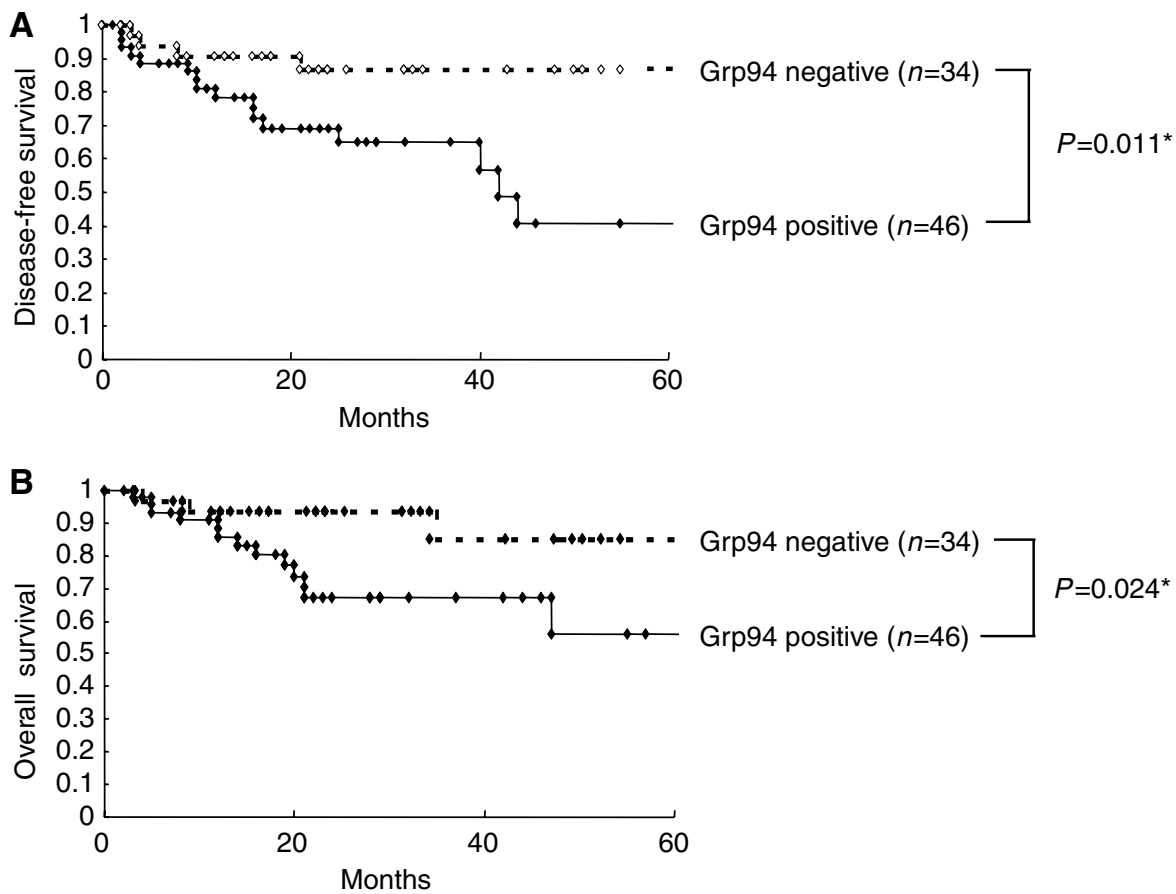

Figure 5 Kaplan-Meier curves for disease-free $(\mathbf{A})$ or overall survival $(\mathbf{B})$ according to Grp94-positive expression in patients with oral squamous cell carcinoma (OSCC) (log-rank test $(\mathbf{A}), P=0.01$ I $(\mathbf{B}), P=0.024$ ). Cases with significantly increased expression of Grp94 protein (immunohistochemical staining score, > 65.56; maximum score of normal tissues) are considered Grp94 positive. Overexpression of Grp94 protein is significantly associated with a poor outcome in patients with OSCC.

whose tissue samples were investigated for Grp94 protein expression by immunohistochemical analysis were statistically analysed. Tumours with significantly increased expression levels of Grp94 protein (immunohistochemical staining score, >65.56; maximum score of normal tissues) were defined as Grp94 positive $(n=46)$. Cases with no or significant downregulation of Grp94 protein expression (immunohistochemical staining score, $<65.56$ ) were considered Grp94 negative $(n=34)$.

Survival curves in relation to Grp94 protein expression are shown in Figure 5. Log-rank survival analysis indicated that Grp94-positive expression was significant both for disease-free survival $(P=0.011$; Figure $5 \mathrm{~A})$ and overall survival $(P=0.024$; Figure $5 B$ ), which suggested that high expression of Grp94 protein in patients with OSCCs was significantly associated with a poor prognosis.

\section{DISCUSSION}

Using a microarray technique, we identified a total of $100 \mathrm{Ca}^{2+}$ binding protein genes aberrantly expressed in OSCC cells. Pathway analysis could further characterise six networks from the 100 genes (Table 1). In addition, the network of the highest significance was generated entirely from 35 of the 100 focus genes (Figure 1), including a number of the $C C L$ and $C X C$ families. Previous studies have shown that chemokine-mediated JAK/STAT activation is critical for phospholipase $\mathrm{C}-\beta$ dependent $\mathrm{Ca}^{2+}$ flux (Li et al, 2000; Lewis, 2001; Thelen, 2001; Soriano et al, 2003). This evidence together with the current results suggests that reduced expression of the main chemokine families, CCL and CXC, disrupts intracellular $\mathrm{Ca}^{2+}$ homeostasis and initiates oral tumorigenesis. The network with the highest significance also contained several cancer-related genes with high expression levels, including DSG2, PRKCA, PLA2G10, and Grp94.

Considerable evidence has shown a significant association between the heat-shock protein 90 (Hsp90) and a wide range of human malignancies, including head and neck cancers (Ito et al, 1998; Baker et al, 2005; Yin et al, 2005). Grp94, also known as gp96, is the ER-resident member of the Hsp90 family constitutively expressed in virtually all cell types (Van et al, 1989) and the most abundant ER chaperon protein showing high homology (50\%) to cytosolic counterpart Hsp90 (Sorger and Pelham, 1987). Increased expression of Grp94 both at the mRNA and protein levels also has been reported in several types of human cancers, such as oesophageal cancer (Wang et al, 2005b), lung cancer (Wang et al, 2005a), breast cancer (Gazit et al, 1999), liver cancer (Lim et al, 2005), and colon cancer (Wang et al, 2005c). We hypothesised that Grp94 also has potential as an emerging therapeutic target of interest for the treatment of oral cancer. However, the status of Grp94 in OSCC remains unclear and, therefore, we selected it for further investigation.

To confirm our hypothesis, we determined the protein/mRNA expression in a series of OSCC-derived cell lines and human primary OSCCs using immunofluorescence, Western blot analysis, qRT-PCR, and immunohistochemistry. Significant increases in Grp94-protein- and mRNA-expression levels were observed in the OSCC-derived cell lines examined compared with the normal oral epithelium. We also detected a comparatively strong tumour celllocalised cytoplasmic Grp94-immunoreaction in primary OSCCs. By evaluating the Grp94 immunohistochemistry scores, significant upregulation was evident in the primary OSCCs compared with normal tissues. While we could not find a significant correlation between Grp94 protein expression status and any clinicopathologic features examined, high levels of Grp94 protein expression was detected even in the OPLs examined. In addition, the current study showed that Grp94 overexpression is closely related to the diseasefree/overall survival ( $P=0.011$ and 0.024 , respectively). Thus, we suggest that Grp94 could be associated with not only early-stage OSCC development but also tumour prognosis.

Interestingly, a recent study has shown that inhibition of Grp94 expression by geldanamycin in chronic lymphocytic leukaemia cells induces apoptosis with modest cytoprotective effects of 
primary haematopoietic progenitors from normal bone marrow (Jones et al, 2004). In addition, targeting cancer cells with an antisense or RNAi procedure against Grp94 has shown increased chemosensitivity or radiosensitivity (Reddy et al, 1999; Kubota et al, 2005). From the therapeutic standpoint, this evidence may provide a novel/effective approach for treating human OSCCs.

In summary, we found novel specific networks of $\mathrm{Ca}^{2+}$-binding protein genes in OSCC cells and identified several candidate genes for molecular targeting, especially for Grp94. Our findings may contribute to an understanding of key biologic functions and pathways of certain $\mathrm{Ca}^{2+}$-binding protein genes associated with
OSCC and should stimulate further investigation into $\mathrm{Ca}^{2+}$ binding protein genes relevant to oral carcinogenesis.

\section{ACKNOWLEDGEMENTS}

We thank Lynda C Charters for editing this article. This study was partly supported by a Grant-in-Aid Scientific Research (no. 16591820) from the Ministry of Education, Culture, Sports, Science, and Technology of Japan.

\section{REFERENCES}

Baker H, Patel V, Molinolo AA, Shillitoe EJ, Ensley JF, Yoo GH, MenesesGarcia A, Myers JN, El-Naggar AK, Gutkind JS, Hancock WS (2005) Proteome-wide analysis of head and neck squamous cell carcinomas using laser-capture microdissection and tandem mass spectrometry. Oral Oncol 2: 183 - 199

Berridge MJ, Lipp P, Bootman MD (2000) The versatility and universality of calcium signalling. Nat Rev Mol Cell Biol 1: 11-21

Bustin SA, Li SR, Dorudi S (2001) Expression of the Ca2+-activated chloride channel genes CLCA1 and CLCA2 is downregulated in human colorectal cancer. DNA Cell Biol 20: $331-338$

Chen D, Davies MP, Rudland PS, Barraclough R (1997) Transcriptional down-regulation of the metastasis-inducing S100A4 (p9Ka) in benign but not in malignant rat mammary epithelial cells by GC-factor. J Biol Chem 272: $20283-20290$

Ding Y, Robbins J, Fraser SP, Grimes JA, Djamgoz MB (2006) Comparative studies of intracellular $\mathrm{Ca}^{2+}$ in strongly and weakly metastatic rat prostate cancer cell lines. Int J Biochem Cell Biol 38: 366-375

Durham AC, Walton JM (1982) Calcium ions and the control of proliferation in normal and cancer cells. Biosci Rep 2: 15-30

Endo Y, Uzawa K, Mochida Y, Shiiba M, Bukawa H, Yokoe H, Tanzawa H (2004) Sarcoendoplasmic reticulum $\mathrm{Ca}(2+)$ ATPase type 2 downregulated in human oral squamous cell carcinoma. Int J Cancer 110: $225-231$

Gazit G, Lu J, Lee AS (1999) De-regulation of GRP stress protein expression in human breast cancer cell lines. Breast Cancer Res Treat 2: 135-146

Haeseleer F, Sokal I, Verlinde CLMJ, Erdjumnet-Bromage H, Tempst P, Pronin AN (2000) Ca (2+)-binding proteins in the retina: structure, function, and the etiology of human visual diseases. J Biol Chem 275: $1247-1260$

Higo M, Uzawa K, Kawata T, Kato Y, Kouzu Y, Yamamoto N, Shibahara T, Mizoe JE, Ito H, Tsujii H, Tanzawa H (2006) Enhancement of SPHK1 in vitro by carbon ion irradiation in oral squamous cell carcinoma. Int $J$ Radiat Oncol Biol Phys 65: 867-875

Huang JK, Huang CJ, Chen WC, Liu SI, Hsu SS, Chang HT, Tseng LL, Chou $\mathrm{CT}$, Chang $\mathrm{CH}$, Jan $\mathrm{CR}$ (2005) Independent $\left[\mathrm{Ca}^{2+}\right] \mathrm{i}$ increases and cell proliferation induced by the carcinogen safrole in human oral cancer cells. Naunyn Schmiedebergs Arch Pharmacol 372: 88-94

Imazawa M, Hibi K, Fujitake S, Kodera Y, Ito K, Akiyama S, Nakao A (2005) S100A2 overexpression is frequently observed in esophageal squamous cell carcinoma. Anticancer Res 25: $1247-1250$

Ishigami T, Uzawa K, Higo M, Nomura H, Saito K, Kato Y, Nakashima D, Shiiba M, Bukawa H, Yokoe H, Kawata T, Ito H, Tanzawa H (2007) Genes and molecular pathways related to radioresistance of oral squamous cell carcinoma cells. Int J Cancer 120: 2262-2270

Ito T, Kawabe R, Kurasono Y, Hara M, Kitamura H, Fujita K, Kanisawa M (1998) Expression of heat shock proteins in squamous cell carcinoma of the tongue: an immunohistochemical study. J Oral Pathol Med 1: 18-22

Jones DT, Addison E, North JM, Lowdell MW, Hoffbrand AV, Mehta AB, Ganeshaguru K, Folarin NI, Wickremasinghe RG (2004) Geldanamycin and herbimycin A induce apoptotic killing of B chronic lymphocytic leukemia cells and augment the cells' sensitivity to cytotoxic drugs. Blood 5: $1855-1861$

Kasamatsu A, Endo Y, Uzawa K, Nakashima D, Koike H, Hashitani S, Numata T, Urade M, Tanzawa H (2005) Identification of candidate genes associated with salivary adenoid cystic carcinomas using combined comparative genomic hybridization and oligonucleotide microarray analyses. Int J Biochem Cell Biol 37: 1869-1880
Kato H, Uzawa K, Onda T, Kato Y, Saito K, Nakashima D, Ogawara K, Bukawa H, Yokoe H, Tanzawa H (2006) Down-regulation of 1D-myoinositol 1,4,5-trisphosphate 3-kinase A protein expression in oral squamous cell carcinoma. Int J Oncol 28: $873-881$

Koch G, Smith M, Macer D, Webster P, Mortara R (1986) endoplasmic reticulum contains a common, abundant calcium-binding glycoprotein, endoplasmin. J Cell Sci 86: 217-232

Kubota H, Suzuki T, Lu J, Takahashi S, Sugita K, Sekiya S, Suzuki N (2005) Increased expression of GRP94 protein is associated with decreased sensitivity to X-rays in cervical cancer cell lines. Int J Radiat Biol 81: $701-709$

Kunzelmann K (2005) Ion channels and cancer. J Membr Biol 205: 159-173 Lakshmikuttyamma A, Selvakumar P, Kanthan R, Kanthan SC, Sharma RK (2004) Overexpression of $\mathrm{m}$-calpain in human colorectal adenocarcinomas. Cancer Epidemiol Biomarkers Prev 13: 1604-1609

Lewis RS (2001) Calcium signaling mechanisms in T lymphocytes. Annu Rev Immunol 19: $497-521$

Li Z, Jiang H, Xie W, Zhang Z, Smrcka AV, Wu D (2000) Roles of PLC-2 and -3 and the PI3K in chemoattractant-mediated signal transduction. Science 287: $1046-1049$

Lim SO, Park SG, Yoo JH, Park YM, Kim HJ, Jang KT, Cho JW, Yoo BC Jung GH, Park CK (2005) Expression of heat shock proteins (HSP27, HSP60, HSP70, HSP90, GRP78, GRP94) in hepatitis B virus-related hepatocellular carcinomas and dysplastic nodules. 14: 2072-2079

Little E, Ramakrishnan M, Roy B, Gazit G, Lee AS (1994) The glucoseregulated proteins (GRP78 and GRP94): functions, gene regulation, and applications. Crit Rev Eukaryot Gene Expr 4: 1-18

Moriyama-Kita M, Endo Y, Yonemura Y, Heizmann CW, Schafer BW, Sasaki T, Yamamoto E (2004) Correlation of S100A4 expression with invasion and metastasis in oral squamous cell carcinoma. Oral Oncol 40: 496- 500

Nelson MR, Chazin WJ (1998) Calmodulin and Signal Transduction. Academic Press: London

Pietas A, Schluns K, Marenholz I, Schafer BW, Heizmann CW, Petersen I (2002) Molecular cloning and characterization of the human S100A14 gene encoding a novel member of the S100 family. Genomics 79: 513-522

Reddy RK, Lu J, Lee AS (1999) The endoplasmic reticulum chaperone glycoprotein GRP94 with $\mathrm{Ca}(2+)$-binding and antiapoptotic properties is a novel proteolytic target of calpain during etoposide-induced apoptosis. J Biol Chem 274: $28476-28483$

Saito K, Uzawa K, Endo Y, Kato Y, Nakashima D, Ogawara K, Shiba M, Bukawa H, Yokoe H, Tanzawa H (2006) Plasma membrane Ca2+ ATPase isoform 1 down-regulated in human oral cancer. Oncol Rep 15: $49-55$

Saito Y, Takazawa H, Uzawa K, Tanzawa H, Sato K (1998) Reduced expression of E-cadherin in oral squamous cell carcinoma: relationship with DNA methylation of 5' CpG island. Int J Oncol 12: 293-298

Shimada K, Uzawa K, Kato M, Endo Y, Shiiba M, Bukawa H, Yokoe H, Seki $\mathrm{N}$, Tanzawa $\mathrm{H}$ (2005) Aberrant expression of RAB1A in human tongue cancer. Br J Cancer 92: 1915-1921

Sorger PK, Pelham HRB (1987) The glucose-regulated protein grp94 is related to heat shock protein hsp90. J Mol Biol 2: $341-344$

Soriano SF, Serrano A, Hernanz-Falcon P, Martin de Ana A, Monterrubio M, Martinez C, Rodriguez-Frade JM, Mellado M (2003) Chemokines integrate JAK/STAT and G-protein pathways during chemotaxis and calcium flux responses. Eur J Immunol 33: 1328-1333

Takahashi K, Kanazawa H, Akiyama Y, Tazaki S, Takahara M, Muto T, Sato K (1989) Establishment and characterization of a cell line (SAS) from 
poorly differentiated human squamous-cell carcinoma of the tongue. J Jpn Stomatol Soc 38: $20-28$

Takenaga K, Nakamura Y, Sakiyama S (1997) Expression of antisense RNA to S100A4 gene encoding an S100-related calcium-binding protein suppresses metastatic potential of high-metastatic Lewis lung carcinoma cells. Oncogene 14: $331-337$

Thebault S, Flourakis M, Vanoverberghe K, Vandermoere F, Roudbaraki M, Lehen'kyi V, Slomianny C, Beck B, Mariot P, Bonnal JL, Mauroy B, Shuba Y, Capiod T, Skryma R, Prevarskaya N (2006) Differential role of transient receptor potential channels in $\mathrm{Ca} 2+$ entry and proliferation of prostate cancer epithelial cells. Cancer Res 66: 2038-2047

Thelen M (2001) Dancing to the tune of chemokines. Nat Immunol 12: $129-134$

Tsai ST, Jin YT, Tsai WC, Wang ST, Lin YC, Chang MT, Wu LW (2005) S100A2, a potential marker for early recurrence in early-stage oral cancer. Oral Oncol 41: 349-357

Van Ginkel PR, Gee RL, Walker TM, Hu D-N, Heizmann CW, Polans AS (1998) The identification and differential expression of calcium-binding proteins associated with ocular melanoma. Biochim Biophys Acta 1448: $290-297$
Van PN, Peter F, Soling HD (1989) Four intracisternal calcium-binding glycoproteins from rat liver microsomes with high affinity for calcium. No indication for calsequestrin-like proteins in inositol 1,4,5-trisphosphate-sensitive calcium sequestering rat liver vesicles. J Biol Chem 264: $17494-17501$

Wang Q, He Z, Zhang J, Wang Y, Wang T, Tong S, Wang L, Wang S, Chen Y (2005a) Overexpression of endoplasmic reticulum molecular chaperone GRP94 and GRP78 in human lung cancer tissues and its significance. Cancer Detect Prev 6: 544-551

Wang XP, Liu GZ, Song AL, Chen RF, Li HY, Liu Y (2005b) Expression and significance of heat shock protein 70 and glucose-regulated protein 94 in human esophageal carcinoma. World J Gastroenterol 11: 429-432

Wang XP, Qiu FR, Liu GZ, Chen RF (2005c) Correlation between clinicopathology and expression of heat shock protein 70 and glucoseregulated protein 94 in human colonic adenocarcinoma. World $J$ Gastroenterol 7: 1056-1059

Yin X, Zhang H, Burrows F, Zhang L, Shores CG (2005) Potent activity of a novel dimeric heat shock protein 90 inhibitor against head and neck squamous cell carcinoma in vitro and in vivo. Clin Cancer Res 10: $3889-3896$ 